\title{
MISTRAL MISTRAL
}

Journal of Latin American Women's

Intellectual \& Cultural History

\section{Innovative Interpretations: Three Recent Studies by Latin American Women Scholars}

David William Foster, Arizona State University, US

To cite this article: David William Foster. 2021. "Innovative Interpretations: Three Recent Studies by Latin American Women Scholars." Mistral: Journal of Latin American Women's Intellectual \& Cultural History 1 (1): 132-140, https://doi.org/10.21827/mistral.1.37512

\begin{abstract}
This article offers a survey of recent work by women scholars in the field of Latin American Studies. Focusing on the writings of Emily Hind, Ana Forcinito, and Sophia Beal, it identifies dominant threads in their research into masculinity and canon formation in Mexico, women filmmakers in Argentina, poetics of memory in Uruguay, and gender and urban spatiality in Brazil. Set within a larger context of the history of Gender Studies within the discipline, this piece provides a vision of pioneering developments in contemporary Latin American Cultural Studies.
\end{abstract}

\section{Keywords}

Latin American Women Scholars; Emily Hind; Ana Forcinito; Sophia Beal 


\title{
Innovative Interpretations: Three Recent Studies by Latin American Women Scholars
}

\author{
David William Foster, Arizona State University, US
}

I am extremely honored to have been asked to contribute to the inaugural issue of Mistral, which promises to be as important in the development of Latin American feminist cultural studies as was the appearance of Letras femeninas, which first appeared in 1974 and has done so much to provide a solid and academically sophisticated foundation in its nearly fifty years of continuous publication. In 2011, Ámbitos feministas began publishing, enriching the intellectual base for the discipline. With the sustained emergence of women in the field of cultural studies and the expanding influence of diverse models of women's studies, gender studies, feminist studies, academic research by women may now be found in every prominent journal in the related disciplines. This might seem like an obvious statement to make, but one cannot exaggerate the shift toward the inclusion of women in critical literary studies over the fifty years since the appearance of Letras femeninas. A quick consultation of the table of contents of an issue from 1974 and one from 2020 of a premier journal like PMLA: Publications of the Modern Language Association is instructive, not to mention the presence of women scholars in the very editorial structure of the journal.

There are feminisms and there are feminisms, of course, and there is virtually no way in which one can generalize among the steady stream of scholarly monographs signed by women in our own area of Latin American cultural and intellectual studies. At least, one would find it a daunting task to attempt an analytical taxonomy of the now rather vast pertinent bibliography. But as a privileged witness to this development - and as the beneficiary of the ways in which it has nourished me deeply as a scholar, teacher, and person-I would like to cling to an overarching notion of the audacious, adventuresome, and intrepid movements that women's scholarship has mostly been engaged in. That is, I continue to expect from scholarship authored by women (as one does from the work of scholars of other so-called subaltern groups) highly innovative ways of viewing texts and cultural processes, a respectable measure of daring in challenging canonical ways of thinking, an often marvelously insouciant way of confronting ossified cant, and a distinctive impatience towards establishment ways (i.e., the tattered remains of the old boys club) of seeing things, such that what most needs to be seen is not getting seen at all.

In this brief essay, I would like to focus on three young women scholars whose work I particularly admire. I admire it for the complexity of the issues they have chosen to deal with, and I admire it for the resolutely refreshing way they approach those issues and 
what they teach me about a discipline that only someone who is intellectually foolhardy thinks he has mastered [sic!].

Of the three anchor literatures of Latin America-Argentina, Mexico, and Brazilthere has been none more officially and intransigently masculinist than the Mexican establishment in the twentieth century. While Argentina, because of the long history of political turmoil in the century, had various competing academic postures in regard to genre and has been, since the return to constitutional democracy in 1983, quite open to feminist and queer studies, Brazilian academic institutions have only recently begun to be more open to something other than a fairly rigid nationalist and masculinist canon: after all, it was not that long ago that Clarice Lispector was a woman writer by name only, as the critical profile available for her was as masculinist as it was for any male writer. But Brazil has always nurtured cultural traditions on the margin of the academy (the study of AfroBrazilian writing seems to have been mostly developed by US-based scholars), and academic criticism in Brazil is now catching up very nicely with this production.

However, in the case of Mexican culture, the effect of the masculinist ideology of post-revolutionary culture has been quite stridently univocal, toward the maintenance and propagation of a unitary masculinist ideal for Mexico that not only justified the systematic elision of women's voices (unless, like Sor Juana they could be put to the use of the masculinist cause in the refutation of clerical hegemony), but also anything that fell short of the macho paragon: Frank Dauster, who worked with such diligence to make Mexican literature so much a center of Latin American studies in the post-World War II period, is alleged to have said that they "all knew" the Contemporáneos were mostly gay, but that they had a gentlemen's [sic.] agreement not to refer to this fact in order to retain credibility with the Mexican literary establishment that would have nothing to do with queer matters (as reported by Oropesa 79). One can understand the multiple marginalizations of the likes of Elena Poniatowska's "siete cabritas," as women, as radical feminists, as often lesbians.

Emily Hind has done much to validate the primacy of an axis of Mexican literature taken from the center of the lair of the "siete cabritas" (adding a number of others along the way), and her Femmenism and the Mexican Woman Intellectual from Sor Juana to Poniatowska: Boob Lit (2010) is now one of the best monographic studies in the field. Dude Lit of 2019 (which she drolly notes that she intended to call Dick Lit until it was pointed out to her it might be offensive...) is now offered as the overarching context of why Femmenism is such an important construal for Mexican literature moving forward; if the cheekiness of "Boob Lit" is delightfully refreshing, the impudence of "Dude Lit" is salutary in its corrective implications of the arrogant primacy of male authors in the institutional contexts she analyzes.

Hind's study is a very complex argument, but in essence it is the sustained examination of what is cued by the title of the first section: "The Civil Engineering of Machos." Hind reminding the reader of all of the ways in which so-called "gendered writing" is almost universally understood as marked as "women's" writing (which must always be understood as a synecdoche for cultural production, although this is not unproblematic because "real" culture by "real" writers - that is men-is intransigently understood as what we customarily identify as "real" literature, in an unending circular argument), is linguistic sleight-of-hand for women's writing, because men's writing, as 
everyone knows [sic.] is not gendered. If all of this reinforces an allegedly outdated gender binary (because progressive scholars that we are, we understand the queer turn), it is because the institutions, whether the casual ones on the street, or the distinguished formal ones in the halls of ivy, remain intransigently masculinist, nay, sexist. And we only kid ourselves if we believe that somehow the American academy is the less sexist one: there is much evidence that they are tied on that score.

Hind may occupy herself with Mexico and the debates within that society over the gendering of culture, but she is fully aware of how hers is unquestionably global thinking about the matter: only the details vary. But there is a major detail here, and it is how the construction of the modern state of Mexico, after the roughly 1910-18 revolution, included the engineering of a consecrated male-centered cultural establishment, that incorporated the traditional genres of literature but also the great new art of the twentieth century: moviemaking. Others have told the masculinist story of the Golden Age of Mexican filmmaking; Hind here tells the story of something like the Golden Age of the literary establishment, reinforced by its overlap with the material power of government and the symbolic power of academic institutions and its many ramifications (the US enjoyed the latter but not the former). This becomes an amazingly efficient machine of male-centered intellectual and artistic privilege, not, of course, without its internal contradictions. But by the time readers reach Chapter 5 of Hind's book, "Bullying Games," there is a clear understanding that this not a metaphor imported from US political correctness, but a transparent signifier of a process of keeping the whole machine in line to ensure the efficiently engineered reduplication of the macho as cultural paradigm.

Hind often runs the risk of readers taking exception with her sassy rhetorical style (it should be obvious that I am not among such readers), but in the end she is not saying anything Mexican women writers and Mexican women critics and intellectuals (see, one cannot get away-yet-from that conceptual marker) haven't said themselves, as evidenced in the public statements in this regard of Sara Sefchovich and Elena Poniatowska, to name only two exceptionally forceful voices. Hind's virtue - at least in this version ${ }^{1}$-is to speak to her fellow (I choose the word here deliberately) Mexicanists about what we are doing: business as usual reinforcing the primacy of "dude lit." As the editor of a journal, receiving manuscripts by colleagues in US Mexican studies, the gentleman's pact that Forster spoke of seems to me pretty much still intact.

Ana Forcinito is a leading interpreter of the culture of transition and redemocratization in contemporary Argentina and Uruguay, and her feminist-grounded work on Argentine filmmaking has provided important scholarly models for understanding the importance of women's voices in the cultural process. Forcinito's monograph Oyeme con los ojos: cine, mujeres, visiones y voces (2018) must be considered an important and exciting critical analysis of an impressive subset of vibrant current Argentine filmmaking: films made by women directors. Nowhere else in Latin America has there emerged such a significant block of women directors as at the current moment in Argentina. These are films that, by any standard, are highly original and provocative, and they have attracted enthusiastic critical attention in Latin America and internationally. All of the directors

\footnotetext{
${ }^{1}$ It remains to be seen if her book will be translated into Spanish and published in Mexico.
} 
Forcinito examines have been the subject of significant scholarly study, and Forcinito's work must be viewed as a major academic intervention in an on-going critical assessment that will consolidate, for the first time in Latin American filmmaking, an inventory of feminist directors who are, quite simply, making cultural history. The important work on feminist filmmaking internationally may have occasionally recognized a woman director from Argentina or Brazil or Mexico, but until now there has not been an inventory sufficient to warrant a monographic study devoted only to Latin American women directors - or, in this case, to those from the major filmmaking center in Latin America that is Argentina. There now is, and Forcinito's work is groundbreaking in that regard.

Forcinito's study is grounded in a straightforward feminist proposition: women as social subjects have heavily circumscribed voices. When they can breach the imperatives of silence, their voices may be truncated, distorted, or otherwise manipulated such that the concept of a direct and transparent articulation of meaning and emotion through overt speech is more an ideological postulate than a sociolinguistic fact. Much scholarly analysis of literature has been based on versions of such a proposition, and studies of women's voice in film and theater, where material speech is at issue, have been similarly grounded. Thus, in a first instance, the importance of Forcinito's proposal is to establish the parameters of these circumstances in contemporary Argentine filmmaking. Where Forcinito's study becomes considerably more original - in the sense of going beyond what is virtually an axiom of feminist cultural studies - is in her interest in what takes the place of direct and unmediated speech in the case of female characters in contemporary Argentine filmmaking by women. Rooting her analysis in the synesthetic proposition "Óyeme con los ojos" and picking up on the Bergman motif of "cries and whispers," Forcinito proposes to examine, what replaces so-called direct speech when these women undertake to articulate their thoughts and feelings. A sociolinguistically adequate account of these women's speech must include an entire range of paralinguistic phenomena that are, ultimately, more important than linguistic expression as conventionally understood.

Forcinito brings to bear Kristevan psychoanalytic theory, which has important groundings in semiotics and discourse analysis, in the attempt to chart how these paralinguistic phenomena are valid and eloquent articulations of the worlds of women's lives that have been made invisible, first, through violent processes of subjection, marginalization, and abjection and, second, through the erasure of direct speech. In the case of film, the camera records the material presence of human bodies, and their processes of expression are inevitably entwined with those bodies and their ways of being in the world. For this reason, it is not just the sounds emanating from bodies - the cries and whispersthat matter, but the inextricable relationship between those sounds and play of a highly problematical bodily presence in the world that gives the film text its particular semiotic quality. It is important to stress that the larger contexts of these characters, the films in which they appear, and the principled fashion in which Forcinito proposes to study them is not "intimist" in the way one customarily understands a psychoanalytic interpretation. Rather, Forcinito is interested in examining how her filmic inventory relates women's experience to larger issues of sociopolitical importance in contemporary Argentina. As she points out in her proposal, the directors at issue do not necessarily claim to be feminists (a problematical designation in Latin American society, as we know), but they do focus their 
work on women's lives and the relationship between those lives and the forces at play in Argentine society.

Óyeme con los ojos won the prestigious 2018 Casa de las Américas Award for Critical Essay in Cuba, and contributes to a broader analysis of post-dictatorship culture in Argentina, as well as Uruguay. In 2011, Forcinito published Los umbrales del testimonio: entre las narraciones de los sobrevivientes y las señas de la dictadura, a study that fits into a large mosaic of research on victims and survivors of the so-called Argentine Holocaust (the use of the word is much contested, but I use it here-Forcinito does not - to underscore the sociohistorical resonance of that particular dictatorship [1976-1983]). The focus of this critical project includes testimonial writing of the sort Forcinito analyzes, but also includes documentary texts, fiction, theatrical works, photography and a huge array of narrative and documentary filmmaking. Although Argentina returned to constitutional democracy in late 1983, almost four decades ago, this material is still being studied and there remains much work to be done, especially in view of the continued lack of access to official government records. Argentina is notable among the countries that experienced authoritarian and neofascist military tyranny in the $1960-90$ period in that there is a sustained attempt, both from official circles and extra-official ones (notably the artistic and academic community), to keep alive the memory of the repression and to prevent a return to similar structures.

Forcinito's 2011 monograph is a careful, detailed, and exemplarily intellectually informed discussion of key texts. She clearly establishes the importance of her corpus, referring to how the Cuban Premio Casa de las Américas has had as one of its categories the testimonial since the early 1970s and how the testimony emerged as a prominent cultural genre in the post-dictatorship era. Indeed, the corpus is far vaster than she can examine in her study, and, hence, one of its greatest strengths is the judicious selection of particularly important and eloquent documents that she can examine in detail. Sensitive to the way in which the legitimacy, authentication, and veracity of testimonial have been questioned-not just in light of theoretical concepts such as the relative intransparency of texts, but the very fact that a personal testimonial implies a filtering parti pris - she does not assume that the testimonial is simply factual. Rather, testimonial writing must be approached as a field of dense meanings and complicated rhetorical strategies that require identification through the critical operation as part of the process of assessing their correspondence with the "reality effect" that testimonial is presumably all about in some sort of privileged fashion.

In 2018, Forcinito published something like a companion volume to Los umbrales, as Intermittences: Memory, Justice, and the Poetics of the Visible in Uruguay. This work deals with that neighboring country to Argentina, where the 1973-1985 dictatorship both paralleled and diverged in its practices from Argentina. The collective force of Forcinito's three monographic studies ranks, by far, as the most intricate and finely analytical coverage of postdictatorship culture in the two countries.

Sophia Beal's writing has none of the hard-edged gaze we find in Hind confrontation of gender politics in Mexican culture, and her focus does not lie with the appalling circumstances of dictatorship and the complexities of re-democratizing culture we find in Forcinito's research. Nevertheless, it provides important models for Latin American cultural studies because of her sustained commitment to analyzing urban space and its relationship to cultural production. It is cliché to observe how something like $70 \%$ or more of Latin 
Americans live in urban areas of over a million people and how the continent is dominated by megalopolises that make the largest cities of the US look almost like small towns: the sprawl of Los Angeles and Dallas are homey cities by comparison to Mexico City and São Paulo. Yet there are few monographic studies that examine in depth the relationship between the metropolitan/megalopolitan experience and the intricacies of a cultural production that must necessarily be viewed as bound up in all of its semiotic dimensions with the urban dynamics of a place. The old model of "the image of the city in" is no longer serviceable because it tends to focus on superficial details, references to physical features or notable examples of the built environment in texts, without inquiring into how the circumstances of urban life bring forth certain types of texts, certain assumptions of texts, and certain expectations of readers. Perhaps photography shows us this best: much of Latin American photography is an integral urban phenomenon, which emerged to provide privileged interpretations of the urban landscape (think of Hildegard Rosenthal in São Paulo or Horacio Coppola in Buenos Aires). It is as if older textual forms like poetry, narrative, and the essay were no longer fully adequate to the task of the new urban experiences.

Concomitantly, culture creates the city, in the sense that it is through culture that we come to sense the working dynamics of urban life. Who can doubt the importance of writing about foreign immigration to understand how these masses moved in and changed the city, in the same way that today a textual production may deal with the patterns of internal migration that lead to the city that is such a prominent feature of Latin American demographics today. Although film certainly deals with much more than urban space (Brazil's much vaunted Cinema Novo was primarily focused on the countryside, peasant struggles for survival, and definitions of Brazil related to the - often barren — soil), film has been a powerful genre for allowing the viewer to experience textures of urban life, with the camera being able to take viewers into a far wider range of urban spaces than they could experience on their own outside the filmic text.

It is in this context that Beal's work is particularly intriguing. Her first monograph, Brazil under Construction: Fiction and Public Works (2013), concerns itself with the bridge between government-sponsored projects, the Brazilian imaginary as a country that might vie for premier status as a bastion of modernity, and examples of cultural production relevant to that imaginary. Iconic in government construction projects was electrification, which continues to play an important part in the national imaginary with the vast Itaipu hydroelectric installation, the largest such generator of power in the world (Itaipu provides electricity to Brazil, Argentina, and Paraguay). Certainly, so much of modernity is based on electrical power, from industrialization on the one hand to the cultural formats of film, radio, and television that are such essential components of cultural production in Brazil. But more than anything else, it was the electrification of the public spaces of the urbanscape that made such a difference, not only extending the clock of public visibility but altering radically how citizens felt about the city at night and its unique possibilities for cultural display. Again, it is not a question of how electrification or any other public works projects (roads, bridges, railways, eventually airports) appear as themes in Brazilian culture, but rather of how they correlate with a paradigm shift in the construction of the imaginary of the city. A major cultural transformation in Latin America is when the shift occurs between the belief that the essence of national identity lies in the countryside and when urban life mounts a powerful 
alternative to that belief. The public works projects Beal focuses on are crucial to that paradigm shift.

Beal's monograph on Brasília is equally innovative, not only because of the way in which it features a city that is still in its infancy by comparison to major metropolitan centers whose roots lie with Luso-Spanish colonial imperialism, but more importantly because of how it is now possible to demonstrate that what is still considered by many an artificial human habitat where people only come together circumstantially for the dull humdrum of the federal bureaucracy has generated a dynamic array of cultural manifestations. The Art of Brasilia (2020) examines a range of cultural production from the Brazilian capital city, which still basically conjures up the project of seventy years ago to construct in the north central desert plain of Brazil a symbol of the country's definitive achievement of international stature. Sort of a modernist project spinning out of control just when modernism was beginning to be seriously questioned, the city has been praised for certain ingenious architectural and design concepts (the official Presidential residence, the Planalto, which was recently remodeled, is stunning), it has also been ridiculed as a paradigmatic example of the inhumanity (with strong authoritarian and fascist overtones) central to modernism and the ways in which the project encoded, despite its pretensions, its own decadence. While for many it is therefore inconceivable that Brasília could be a vibrant cultural center (and it is perhaps questionable whether it has been in an official sense), the parameters have precisely ensured areas of contact, conflict, friction, and ignition that have produced a wide range of extremely interesting contestatorial and countercultural production. It is this material that Beal undertakes to examine, covering the first decade and a half of the twenty-first century.

Beal's work is a significant example of current cultural studies because it is quite singular in its approach to Brasília, a city whose cultural production has not previously been examined. São Paulo and Rio de Janeiro get all the attention in terms of the urban interactions of culture, and there are cities like Curitiba (almost four-hundred years old), Belo Horizonte, and Porto Alegre that are almost never talked about in terms of focal points of particularly unique cultural emphases (Curitiba's well-maintained and celebrated consciousness of its kaleidoscope of immigrant origins, for example), so it is somewhat ironic that a newcomer like Brasília might deserve the scrutiny Beal affords it. But what is important about Beal's interest in Brasília as a city that one might quickly dismiss as lacking in any sort of sustained cultural consciousness is the way in which she provides detailed analyses of significant works that go against certain prevailing beliefs by which large conservative sectors still cling to regional culture as the essence of Brazilian character and creativity: one can hardly claim that there is anything "regional" about Brasília, since its very modernist conception was to be the antithesis of regional conceptions of the nation.

Necessarily, Beal pays particular attention to popular culture (an image of the pop singer tatiana nascimento [sic.] is featured on the book's cover), the analysis of which does not hold much interest for the Brazilian critical establishment. Indeed, it is not surprising that popular culture may more define Brasília than legendary high-culture practices that continue to be tied to Rio and São Paulo institutions, particularly traditional narrative fiction. The need to provide an adequately intelligent critical analysis of popular cultural practices is not only the necessary recognition of a sector of cultural production that is there and, as a consequence, must be taken into account, but it is also the recognition of what might be a particularly 
distinctive inflection of this singularly unusual urban space. Beal's monograph is something like an intellectual investment, born of the conviction that the time has come to go beyond the trite observation that Brasília lacks the conditions to generate anything other than circumstantial cultural texts. Beal proves otherwise, and the innovation of her study is that she has had the leap of critical imagination to undertake a project that the Brazilian academic establishment has yet to execute.

These three studies are all extremely innovative in their approach to certain facets of Latin American culture. Only two of them-Hind's and Forcinito's - would qualify as specifically feminist, although one could argue that Beal's is indirectly for the specific inclusion of women cultural protagonists, a fact that is evident beginning with the cover of The Art of Brasilia. What is eminently important about these three studies is that each offers a powerful model designed to shift our perception of the cultural record. In the case of Hind, it is nothing less than the whole issue of institutional canon construction in a country of particular prominence in Latin American literature and among US scholars of Latin American literature. In the case of Forcinito, it is the urgent question of how subalternities, especially women, can construct meaningful and persuasive voices without being merely supplements to dominant masculinist discourses. And in Beal's case, it lies with providing highly articulate challenges to conventional ways of seeing the relationship between city and cultural production. All deserve to be read carefully and cited often.

\section{Works Cited}

Beal, Sophia. 2020. The Art of Brasília 2000-2019. New York: Palgrave Macmillan.

Beal, Sophia. 2013. Brazil under Construction: Fiction and Public Works. New York: Palgrave Macmillan.

Forcinito, Ana. 2018. Intermittences: Memory, Justice, and the Poetics of the Visible in Uruguay. Pittsburgh: Univerity of Pittsburgh Press.

2018. Óyeme con los ojos: cine, mujeres, visiones y voces. La Habana: Fondo Editorial Casa de las Américas.

2012. Los umbrales del testimonio: entre las narraciones de los sobrevivientes y las señas de la posdictadura. Madrid: Iberoamericana; Frankfurt-am-Main: Vervuert.

Hind, Emily. 2019. Dude Lit: Mexican Men Writing and Performing Competence, 1955 2012. Tucson: University of Arizona Press. 
2010. Femmenism and the Mexican Woman Intellectual from Sor Juana to Poniatowska: Boob Lit. New York: Palgrave Macmillan.

Oropesa, Salvador A. 2003. The Contemporáneos Group: Rewriting Mexico in the Thirties and Forties. Austin: University of Texas Press.

Poniatowska, Elena. 2000. Las siete cabritas. México, D.F.: Ediciones Era. 